\title{
低蛋白食の副腎皮質ホルモン分泌に及ぼす影響 \\ Studies on. the Influence of Low Protein Diet upon \\ the Excretion of the Adrenocortical Hormone
}

(昭和 36 年 10 月 22 日受理)

藤 本 省 -

(Seiichi Fujimoto)

1) In those taking a low protein diet, the secretion of adrenocortical hormone decreased to the minimum in the 2 nd $~ 3$ rd weeks, and afterwards showed a little increase without a full recovery.

2) It was made clear by diet surveyings that calorie and total protein in the diet were sufficient but the protein-score of the diet was remarkably low in priests who were in the practice of religious austerities on Zenshu (Zenshu-Sodo) as they were not in the habit of taking animal protein. These facts were considered as very significant in the daily life of such priests.

锗論

副腎皮質ホルモンの生理作用に関しては最近各方活に おいて深く研究せられており，生体が各種の内的外的生 活環境の変化に対して適空せん上する場合に主役を演ず っことが漸次明らかにせられてきた。当教室に㧍いて は従来より盆白掑取量の変化に対寸る生体の適応作用に ついて研究㧍行われているが副㹂皮質ホルもンはその Glucocorticoid \& Ketosteroid も共に蛋白代謝江関倸 寸るホルモンであるから，恐らくこれらホルエンの分泌 も食蛋白の変化に伴二て変化することが尔想せられる。 しかし従来この方面の研究は非常に少なく, 第 4 回国際

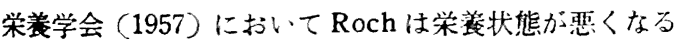
と性ホルモン分泌が低下するこ上を報告し，蛋白欠泛状 態汇おいては内分泌腺機能低下の梯相の見られることを 明らかにしたここの性ホルモンの一部は副督皮質よりも 17一KS として分祕せられ蛋白代謝に影響するものであ る。

その他正木 ${ }^{2)}$ 注牛, 山羊について尿排泄 17-K S等が 饥餓又は低蛋白食時に堿少することを見ている。このよ らに副腎皮質ホルモンが飥饿あるいは低蛋白食時におい て影響を受けることを明らかにした報告はあるがいずれ も局部的の観察であり，その生理的意義や他の生理機能 との関連性等については触れるところがないのである。

たまたまわが教室においては成人の蛋白所要量を決定 するために数多くの人体低蛋白食実験が行われることに なったので，著者はこの機会を利用して副腎皮質ホルモ
ン分泌が低蛋白食に依っていかに変化寸るかを系統的に 観察しかつ卡の生理的意義在明らかにせん上して本研究 在企てた

\section{実 駼方 法}

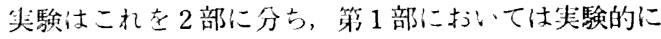
低蛋白食在被唡者に与えて蛋白代谢を変化せしめ，その 間の尿排泄副腎皮質ホルモン索時期を追。て测定観察し た。第２部嫦時低蛋白食を常食上せる僧侣について， 尿排泄副緊皮斦ホルモン是を測定したるものである。い ずれの場合にも副腎皮質ホルモンとしては 17-OHCS，

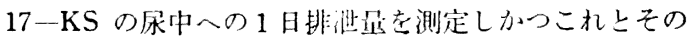
提取食蛋白最，尿排泄空素量，空热出納等老同時に測定 して蛋白代㴬との関速性を明らかにする一方体重の消長 や基磷代謝，血沙P. B. I. の変化等老七同時に測定して

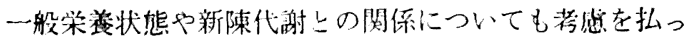
た。以下各实験方法の絊部について項を分って詳述する こととする。

\section{1）低蛋白食奏䮖}

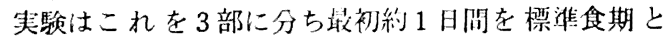
し, 熱星 $2500 \sim 2700 \mathrm{Cal}$, 蛋白量 $70 \mathrm{gr}$ (蛋白洒 73\%) を与え，同時にビタミン，塩類等の微是栄菻素の配分を 充分考虑しつつ体重，蛋白代即ならびに生活条件を規正 し，ほぼ一定平衡状望に到達したのを確認したる後低蛋 白食実駼に人った。こして一定期閒一定の低蛋白食を続 行して後, 約 1 週間を恢復食期とし標源食作あるいはそ れ以上に蛋白の豊富な食倻を与文, 実駼による影響の恢 
復する状況を観察した。この間の食船は献立通りのもの を悉く被検者に食せしめ余すところのないようにしたこ とはいらまでもない。低蛋白食としては次に述べるよう に短期間これを与えたもの上長期間与えたものの 2 群の 実験を行なったがその何机においてて蛋白の質と量との 関係を種々に変えてその影製在観察することにした。即 ち第1の㬰䁐は低蛋白食在約 3 週問続行したものであっ て，仮に短期低蛋白食実験と名付けることとする。この 実験において与えた低蛋白食の特性は第1 表に示されて いる、A群は食蛋白はい寸゙れも動植物性の食品によって 与えたものであって、これ在 3 種類に分ち、1)は栄盖価 の高い動物性食品在上し，丁度その必須アミ／酸の必

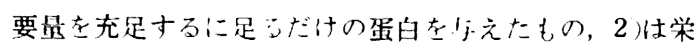
衰価の低い植物性食品を主レし，蛋白摄取量を多くして

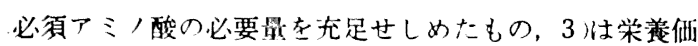
の低い植物性蛋白主少しか与えナ゙に必須了ミ，酸不足
の状態においたものである。

B群はこの 3）の植物性蛋白食を基本食とし，これに アミノ酸を添加してその必要最を充足せしめたものであ る。これにも2 種類の群を区別し 1) は単に必須アミノ 酸の不足量のみを添加して充足せしめたもの，2)はこれ に更に非必須アミノ酸を添加して蛋白およびアミノ酸椇 取量を充分となし， $1 \mathrm{gr} / \mathrm{kg}$ の程度となしたるものであ る。但しこの何れの場合にも必須アミノ酸必要量として は F. A. O ( $^{3)}$ にて決定せられた成人男子体重 $\mathrm{kg}$ 当り必 要量を採用した。

第 2 の実験は長期低蛋白食実験であって低蛋白食を12 週間続行した。低蛋白食としては良質のものを少量あた えた群と低質のものをやや多量に与えたものの 2 種類が あり，いずれも各必須アミノ酸を充足するに足るだけの 蛋白はとっている。その他本表に記载せる蛋白価の計算 法の詳紐は吉村教授訳 : 蛋白必要量にくわしく書かれて

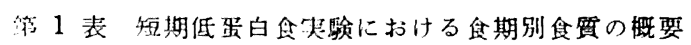

A 群 低蛋白食実験

\begin{tabular}{|c|c|c|c|c|c|c|c|}
\hline & 被 垤 者 & & & 標 10 蕉 䦎) & 試 $(26 \text { 卧 開 })^{\text {食 }}$ & 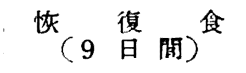 & $\begin{array}{l}\text { 低蛋白食の } \\
\text { 特徽 }\end{array}$ \\
\hline \multirow{6}{*}{1} & $\mathrm{Sk}$ & 企 & 㩊 価 & $2760 \mathrm{Cal}$ & $2750 \mathrm{Cal}$ & $2715 \mathrm{Cal}$ & 兵がよく \\
\hline & & 蛋 & 白 量 & $\begin{array}{c}735 . \mathrm{gr} \\
(1.07 \mathrm{gr} \mathrm{kg} \text { day })\end{array}$ & $\begin{array}{c}42.1 \mathrm{gr} \\
(0.61 \mathrm{gr} / \mathrm{kg} \text { day })\end{array}$ & 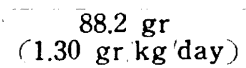 & 量が少ない \\
\hline & $(68.7 \mathrm{~kg})$ & 东 & 白 比 & $73 \%$ & $93 \%$ & $79 \%$ & \\
\hline & $\mathrm{Ha}$ & 食 & 敕 低 & $2540 \mathrm{Cal}$ & $2600 \mathrm{Cal}$ & $2600 \mathrm{Cal}$ & \\
\hline & & 4 & 白 最 & $\left(\begin{array}{c}70.1 \mathrm{gr} \\
\left(1.37^{\mathrm{gr}} / \mathrm{kg} \text { day }\right.\end{array}\right)$ & $\begin{array}{c}30.1 \mathrm{gr} \\
(0.58 \mathrm{gr} \mathrm{kg} \text { day })\end{array}$ & $\left(\begin{array}{c}70.1 \mathrm{gr} \\
(1.37 \mathrm{gr} / \mathrm{kg} \text { day }\end{array}\right)$ & \\
\hline & $51.7 \mathrm{~kg}$ ) & 位 & 白 比 & $73^{\circ}$ & $95^{\circ} \%$ & $79 \%$ & \\
\hline \multirow{6}{*}{2} & $\mathrm{Ta}$ & 战 & 㭗 研 & $2600 \mathrm{Cal}$ & $2720 \mathrm{Cal}$ & $2590 \mathrm{Cal}$ & 翼が悪く \\
\hline & & 桑 & 白 是 & $(1.28 \mathrm{gr} / \mathrm{kg} / \mathrm{day})$ & $\begin{array}{c}42.8 \mathrm{gr} \\
(0.78 \mathrm{gr} / \mathrm{kg} / \text { day })\end{array}$ & $\begin{array}{c}73.3 \mathrm{gr} \\
(1.34 \mathrm{gr} / \mathrm{kg} \text { day })\end{array}$ & 量が多い \\
\hline & $(54.6 \mathrm{~kg})$ & 蛋 & 白 比 & $73 \%$ & $73^{\circ} \%$ & $79 \%$ & \\
\hline & Sa & 食 & 袊 佂 & $2550 \mathrm{Cal}$ & $2590 \mathrm{Cal}$ & $2720 \mathrm{Cal}$ & \\
\hline & & 然 & 白 最 & $\left(\begin{array}{c}70.1 \mathrm{gr} \\
\left(1.22^{\mathrm{gr}} \mathrm{kg} \text { day }\right)\end{array}\right.$ & 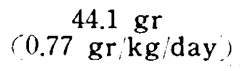 & $\begin{array}{c}76.5 \mathrm{gr} \\
(1.38 \mathrm{gr} / \mathrm{kg} / \mathrm{day})\end{array}$ & \\
\hline & $(5 / .6 \mathrm{~kg})$ & 承 & 白 比 & $73 \%$ & $73 \%$ & $78 \%$ & \\
\hline \multirow{7}{*}{3} & & & & (14日間) & (20日閒) & (8 日 閑) & \multirow{7}{*}{$\begin{array}{l}\text { 貿も悪く } \\
\text { 量も少ない }\end{array}$} \\
\hline & $\mathrm{Ue}$ & 位 & 価 & $2660 \mathrm{Cal}$ & $2660 \mathrm{Cal}$ & $2660 \mathrm{Cal}$ & \\
\hline & & 乐 & 毁 & $\left(\begin{array}{c}73.2 \mathrm{gr} \\
\left(1.27^{\mathrm{gr} / \mathrm{kg} / \mathrm{day}}\right)\end{array}\right.$ & $\begin{array}{c}32.1 \mathrm{gr} \\
0.55 \mathrm{gr} / \mathrm{kg} \text { day })\end{array}$ & $\begin{array}{c}87.0 \mathrm{gr} \\
(1.51 \mathrm{gr} / \mathrm{kg} / \text { day }\end{array}$ & \\
\hline & $(57.5 \mathrm{~kg})$ & 舟 & 比 & $70 \%$ & $63 \%$ & $91 \%$ & \\
\hline & Ko & 芷 & 価 & $2510 \mathrm{Cal}$ & $2550 \mathrm{Cal}$ & $2550 \mathrm{Cal}$ & \\
\hline & & 蛋 & 白 量 & $\left(\begin{array}{c}70.0 \mathrm{gr} \\
\mathrm{gr} / \mathrm{kg} / \mathrm{day})\end{array}\right.$ & $\begin{array}{c}30.8 \mathrm{gr} \\
(0.55 \mathrm{gr} / \mathrm{kg} / \mathrm{day})\end{array}$ & $\begin{array}{c}82.5 \mathrm{gr} \\
(1.50 \mathrm{gr} / \mathrm{kg} / \mathrm{day})\end{array}$ & \\
\hline & $(54.8 \mathrm{~kg})$ & 蛋 & 白 比 & $70 \%$ & $63 \%$ & $92 \%$ & \\
\hline
\end{tabular}


B 群 非必須アミノ酸添加低蛋白食夹験

\begin{tabular}{|c|c|c|c|c|c|c|c|c|c|}
\hline & 被 検 者 & & & & 標 滥 & 食 & 低 蛋 白 食 & $\begin{array}{l}\text { 添加アミノ酸及 } \\
\text { 摄取総単白罝 }\end{array}$ & $\begin{array}{l}\text { 低蛋白食の } \\
\text { 徽 }\end{array}$ \\
\hline \multirow{6}{*}{1} & \multirow{3}{*}{$\begin{array}{c}\mathrm{Ku} \\
24 \quad \delta \\
(66.8 \mathrm{~kg})\end{array}$} & \multicolumn{3}{|c|}{ 食養"価 } & $2720 \mathrm{Cal}$ & & $2770 \sim 2780 \mathrm{Cal}$ & $\begin{array}{c}\text { 全掑取聜糸 }(\mathrm{gr}) \\
10.56\end{array}$ & \multirow{3}{*}{$\begin{array}{c}\text { 必須アミノ酸 } \\
+ \\
\text { 非必須アミノ酸 }\end{array}$} \\
\hline & & & 白 & 暴 & $82.5 \mathrm{gr}$ & & 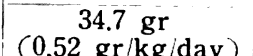 & $66.0 \mathrm{gr}$ & \\
\hline & & 蟫 & 白 & 比 & $70 \%$ & & $61 \%$ & & \\
\hline & $\mathrm{Ue}$ & 食 & 養 & 価 & $2470 \mathrm{Cal}$ & & $2480 \sim 2500 \mathrm{Cal}$ & 8.86 & \\
\hline & \multirow{2}{*}{$\begin{array}{c}23 \quad \delta \\
(56.8 \mathrm{~kg})\end{array}$} & 蛋 & 白 & 量 & $70.2 \mathrm{gr}$ & & $\begin{array}{c}29.3 \mathrm{gr} \\
(0.52 \mathrm{gr} / \mathrm{kg} \text { day })\end{array}$ & $\begin{array}{c}55.4 \mathrm{gr} \\
(0.98 \mathrm{gr} / \mathrm{kg} / \mathrm{day})\end{array}$ & \\
\hline & & 要 & 白 & 比 & $71 \%$ & & $61 \%$ & $33 \%$ & \\
\hline \multirow{6}{*}{2} & $\mathbf{K a}$ & 食 & 落 & 洒 & $2480 \mathrm{Cal}$ & & $2600 \sim 2650 \mathrm{Cal}$ & 4.86 & \multirow[t]{6}{*}{ 必弱アミノ酸 } \\
\hline & $23 \hat{\jmath}$ & 蛋 & 白 & 量 & $71.4 \mathrm{gr}$ & & $\begin{array}{c}29.3 \mathrm{gr} \\
(0.53 \mathrm{gr} / \mathrm{kg} / \mathrm{day})\end{array}$ & $\begin{array}{c}30.4 \mathrm{gr} \\
(0.55 \mathrm{gr} / \mathrm{kg} / \text { day })\end{array}$ & \\
\hline & $(30.2 \mathrm{~kg})$ & 蛋 & 白 & 比 & $71 \%$ & & $61 \%$ & $71 \%$ & \\
\hline & $\mathrm{Ot}$ & 食 & 落 & 価 & $2400 \mathrm{Cal}$ & & $2490 \mathrm{Cal}$ & 4.74 & \\
\hline & \multirow{2}{*}{$\begin{array}{c}22 \hat{\jmath} \\
(54.9 \mathrm{~kg})\end{array}$} & 贾 & 白 & 量 & $68.9 \mathrm{gr}$ & & $\begin{array}{c}28.6 \mathrm{gr} \\
(0.52 \mathrm{gr} / \mathrm{kg} / \text { day })\end{array}$ & $\begin{array}{c}29.7 \mathrm{gr} \\
(0.54 \mathrm{gr} / \mathrm{kg} / \text { day })\end{array}$ & \\
\hline & & 蛋 & 白 & 比 & $71 \%$ & & $61 \%$ & $71 \%$ & \\
\hline
\end{tabular}

ある。また計算に用いた食品の必須アミ，酸含有量は M. L. Orr and B.K. Watt ク表によるこレにした。

被検者はいずれも健㴍成人男子（22 才より 26 才の医 科学生）を選び実験期間中は研究空内に起居および食佴 をせしめ採血、採尿等の外は日常の勉学に近い生活卒つ
うけさせた。また可及的に每朝朝食前に体至忞も測定せ しめ体温脈博等を測らしめて疾病の早剒発見に遗憾のな いようにした。そして各人に尿を毎朝 8.00 時を界レし 1 日全量を攝取せしめ，これにトルオールを添加して冷暗 貯蔵しこれについて窒素排测量在测定する一方，抵取食

第 2 表 長期低蛋白食帮験における食期別食質の概要

\begin{tabular}{|c|c|c|c|c|c|c|c|c|}
\hline & 被蚞 者 & & & & ${ }^{\text {標 }}(9 \text { 準 間 })^{\text {食 }}$ & 試 $(100 \text { 日鋛 })^{\text {食 }}$ & 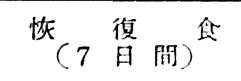 & $\begin{array}{l}\text { 低蛋白食の } \\
\text { 特特 }\end{array}$ \\
\hline \multirow{6}{*}{1} & $\mathrm{Ka}$ & 食 & 菱 & 価 & $2450 \mathrm{Cal}$ & $2440 \sim 2580 \mathrm{Cal}$ & $2570 \mathrm{Cal}$ & \multirow{6}{*}{$\begin{array}{l}\text { 貎が艮く } \\
\text { 只少ない。 }\end{array}$} \\
\hline & $23 \hat{\jmath}$ & 蛋 & 白 & 量 & $\begin{array}{c}73.5 \mathrm{gr} \\
(1.34 \mathrm{gr} / \mathrm{kg} / \text { day })\end{array}$ & $\begin{array}{c}29.8 \mathrm{gr} \\
(0.54 \mathrm{gr} / \mathrm{kg} / \mathrm{day})\end{array}$ & $\begin{array}{c}73.5 \mathrm{gr} \\
(1.30 \mathrm{gr} \mathrm{kg} \text { day })\end{array}$ & \\
\hline & $(548 \mathrm{~kg})$ & 采 & 白 & 価 & $69 \%$ & $96 \%$ & $70 \%$ & \\
\hline & & 食 & 玈 & 価 & $2690 \mathrm{Cal}$ & $2630 \sim 2980 \mathrm{Cal}$ & $2970 \mathrm{Cal}$ & \\
\hline & $26 \hat{\jmath}$ & 要 & 白 & 量 & $\begin{array}{c}90.5 \mathrm{gr} \\
(1.35 \mathrm{gr} / \mathrm{kg} / \mathrm{day})\end{array}$ & $\begin{array}{c}35.6 \mathrm{gr} \\
(0.54 \mathrm{gr} / \mathrm{kg} / \mathrm{day})\end{array}$ & $\begin{array}{c}90.5 \mathrm{gr} \\
(1.35 \mathrm{gr} / \mathrm{kg} / \mathrm{day})\end{array}$ & \\
\hline & $(66.8 \mathrm{~kg})$ & 蛋 & 白 & 価 & $69 \%$ & $96 \%$ & $70 \%$ & \\
\hline \multirow{6}{*}{2} & $\mathrm{Ta}$ & 食 & 鍌 & 価 & $2510 \mathrm{Cal}$ & $2530 \sim 2760 \mathrm{Cal}$ & $2760 \mathrm{Cal}$ & \multirow{6}{*}{$\begin{array}{l}\text { 䊖は悪いが } \\
\text { 品は多い。 }\end{array}$} \\
\hline & $25 \delta$ & 蛋 & 白 & 量 & $\begin{array}{c}76.5 \mathrm{gr} \\
\left(1.32^{\mathrm{gr} / \mathrm{kg} / \text { day }}\right)\end{array}$ & $\begin{array}{c}45.0 \mathrm{gr} \\
(0.78 \mathrm{gr} / \mathrm{kg} / \text { day })\end{array}$ & $\left(\begin{array}{c}76.5 \mathrm{gr} \\
\left.32^{\mathrm{gr}} / \mathrm{kg} / \mathrm{day}\right)\end{array}\right.$ & \\
\hline & $(57.8 \mathrm{~kg})$ & 蛋 & 白 & 価 & $69 \%$ & $67 \%$ & $70^{\circ}$ & \\
\hline & $\mathrm{Ya}$ & & 港 & 価 & $2510 \mathrm{Cal}$ & $2530 \sim 2660 \mathrm{Cal}$ & $2760 \mathrm{Cal}$ & \\
\hline & $25 \hat{\jmath}$ & & 白 & 量 & $\left(\begin{array}{c}76.5 \mathrm{gr} \\
\left(1.30^{\mathrm{gr}} / \mathrm{kg} / \mathrm{day}\right)\end{array}\right.$ & $\begin{array}{c}45.0 \mathrm{gr} \\
(0.77 \mathrm{gr} / \mathrm{kg} / \mathrm{day})\end{array}$ & $\left(\begin{array}{c}76.5 \mathrm{gr} \\
(1.32 \mathrm{gr} / \mathrm{kg} / \text { day })\end{array}\right.$ & \\
\hline & $(59.0 \mathrm{~kg})$ & 蛋 & 白 & 価 & $69 \%$ & $70 \%$ & $70 \%$ & \\
\hline
\end{tabular}


蛋白空素神を実測して每日の空素出納を锶察した。また 一方その尿については 17-kS, 17-OHCS 等の副盈皮 質ホルモン定昌才るほか，ウロビリン，ウロビリノー ゲン、糖、蛋白等の一般尿検查を行なった，又每週 1 回 基礎代謝を測定したる後，早朝空腹時の血液についてそ の血清 P. B.I. その他の血液性状の榆查をも行なった。 血液性状の䊼紐については吉岡が別途に報告寸るはす゚で あるからここに沈触れないことにする。以下これらの測 定法の概様について項を分って述心゙ることにする。

\section{a) 空素出科実䮦}

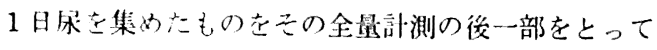

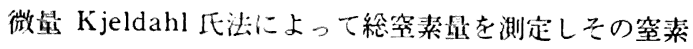
濃度さ1日瓜量に乘して1日の排泄虽在算出した。一方 每食期の始かと終门で各3４日間の大便全到を提取し， こ机吉䩐燥碎粉して问梯空素品を測定し，また他方食品

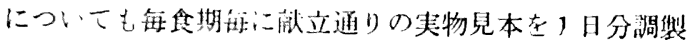

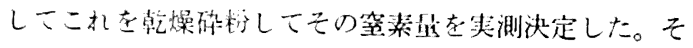

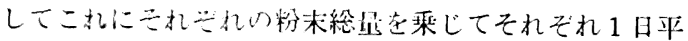

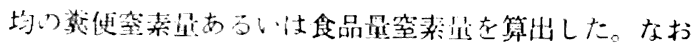

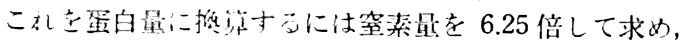

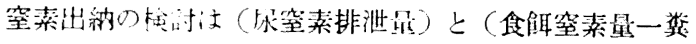
便空案量)上の差こして計算した。以後記速には前者を

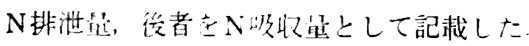

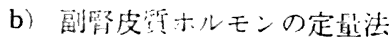

午前8.91時より翌朝午前 8.00 時に到る全尿在正確に

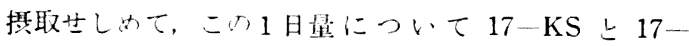
OHCS 在測定した これら耐副婜皮所ホルモンの测定に はいろ:ろの方法がらが著者が用いたのは 17一KSに ついて仗発色度応上してZimmerman 文応を用いる增 田氏変法けであり，17-OHCSに関しては Reddy 氏法 を基にした鳥居氏変法りである。な扩17-KS の測定に は层 50 c c. 17 OHCS の場合には尿 10 c.c. 在用いて

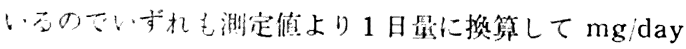

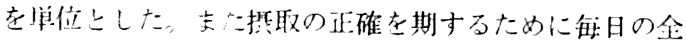
尿について総 Creatinin ${ }^{(j)}$ を測定，その値の正常なるこ と在到繁皮䝿ホルテン测定の条件とし総 Creatinin に甚しい変動ある時は二机在避けるようにした。

c) 花碳代㴬の測定

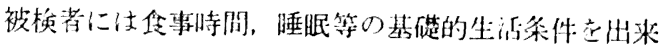
るだけ一定に打しし，研究室内测定室に很泊せしめて 翌朝觉醒時 7 -8 時の間に移台に横たわったままの状熊 で测定した。

空温は特に一定に规正寸ることはしなかのたが伯し快 適なる依具温度の中で測定しているので潩境父温自体の 影響はないと思われる。

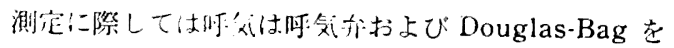

用いて各 6 分間宛 3 回接取し，その 1 部を労研式瓦斯分 析器に移して分析した。得られた測定值は 3 回値の平均 か, あるいは異常と思われる値をのぞいた 2 回の值の平 均である。また死斯捊取洔被検者はしばしば睡眠に陥り 易いのであるが絶えず覚醒状態を保つよう注意を払っ た。

d) 血清 P. B. I. の測定

基硭代謝の日にその呼吸无斯を撜取したる後に被検者 の时静脈より採血し血清を分離して，それについて Baker 氏アルカリ灰化法》で血清 P. B. I. を測定した。 その詳紐は Baker により報告せられているが，その要 旨は血清に含まれた蛋白を沈澱せしめ、これを灰化して 蛋白結台沃度を無機の沃度に変化せしめる。この夭度量 を沃度セりュームイオン裉色反応促進効果の大きさより 定量するのである。この反応速度は液温によって影響せ られるから本笑驗においては褪色時間の測定に際しては 常に試験管を $39^{\circ} \mathrm{C}$ の恒温槽に浸して温度条件を一定と するようにした。

2）僧侶生活者に抢ける調查

前記の人体低蛋白食実験は期間に一定の制限があり， 短きは 3 週間長くも 3 力月に過ぎない。この点長期低蛋 白食の影警を明らかにするために禅宗僧堂における修業、 僧が全く動物食を聆取せずかつ長期に亘って習帽的に低 蛋白食生活であうことに着眼し，その食解分析と尿排泄 副精皮犋ホルモンの定量を計画した。

しかし近来僧侶といえども肉食するものが漸次增加の 現状にかんがみ僧堂の中でも遠く人里離れた比微山延暦 寺において特に啟重なる菜食と戒律を守っている数名の 僧侣に対照を求めた。調查は 1960 年 7 月を選び被検者 は比愹山の内釈迦堂, 浄土院, 横川中堂, 西尊院の各坊 に修業中の年令 26 才より 51 才に亘る健康なる僧侣 6 名を検査対照とした。いずれも事前健康診断をなし心電 図，検尿，血圧等を検查してその健康状態を確認した。 検査者は約 1 週間各僧堂に缩泊して被検者と生活を共 にしつつ; 午前 3 4 時修業僧の起床前, 体重, 血圧, 基碮 代测，血液検查を実施の起床時を境として尿を捸取せし め正磪に 1 日量を測定した。かつ被検尿については毎日 総 Creatinin を測定して採尿の正確性を確認し，その OHCS を測定したのである。また同時に尿中蛋白，糖， ウロビリノーゲン，ウロビリン，の検査を実施した。一 方食䬣に関してはいちいち材料について各人毎食の使用 重量を測定し，捸取量を明らかにし，5 日間を分析して その平均値を求め, これを各被検者の定食とした。その 分析表は第 3 表の如くである。 
第14巻 第 4 号

第 3 表 借堂生活 $の$ 食飭調查表

\begin{tabular}{|c|c|c|c|c|c|c|c|c|}
\hline 柀㭘者 & 年 呤 & 体重 & 食湌 価 & $\begin{array}{l}\text { 蛋 白 } \\
\text { (gr/day) }\end{array}$ & $\begin{array}{c}\text { 蛋白 量 } \\
(\mathrm{gr} / \mathrm{kg} / \mathrm{day})\end{array}$ & 蛋白洒 & 備 & 考 \\
\hline Ar & 30 & 57.8 & $2365 \mathrm{Cal}$ & 63.6 & 1.10 & $62 \%$ & & \\
\hline $\mathrm{Ha}$ & 26 & 56.0 & $2557 \quad \prime \prime$ & 66.9 & 1.19 & $62 " \prime$ & & \\
\hline $\mathrm{Ku}$ & 51 & 56.3 & 2481 & 64.8 & 1.27 & $62 \prime \prime$ & & \\
\hline Ho & 31 & 61.0 & 2386 & 57.1 & 0.94 & $63 \prime \prime$ & & \\
\hline $\mathrm{Na}$ & 29 & 48.6 & 2025 & 54.3 & 1.12 & $63 \prime \prime$ & & \\
\hline Ko & 37 & 53.5 & 2781 & 63.4 & 1.19 & $62 \prime$ & & \\
\hline 平均 & & 55.5 & 2423 & 61.7 & 1.14 & $63 \prime \prime$ & & \\
\hline
\end{tabular}

実 験 成 績

\section{1 低蛋白食実験}

1）被検者の一般状態：被検者の自覚症状としては各 実験を通して，低蛋白食に入る上 $2-3$ 週間後において 身体の異和を訴えるようになり，頭痛，倦忠感, 気力喪失 等と其に食欲不振, 胸やけ等の胃部不快感が顕著になっ てくる。食欲不振，胸やけ等を主上する胃障碍 は献立てられた低蛋白食が単調で倦き易く且平 常の食餌と著しく異ることおよび献立てに糖分 が多くなっているこ上等が関倸するであるう。 䓡急感や気力培失上いった現象汇長くつうくも のではなく，一定の時期をすきる自然に消失 して何の異常も認めないままに実験終了に及ん でいる。これらの現象は多分に主観的な自覚意 就が影響しているが，しかしこの場合には実際 に体蛋白の消耗に異常が起っているのであるか ら根本的原因をそこに求めることが合理的であ 万5。それはこれらの街候が後述する如く副腎 皮質ホルモンの分泌曲線とよく一致して消長し ているからであって，恐らくは低蛋白食の結果 現われる各種内分泌腺の機能低下の結果であろ らと考えられる。

次に体重は低蛋白食期においては摽準食期に 比して総体に甚しい動摇を示すものが多いこと は森田8)が指摘したところであるがこの事は著 者の実験においても認められた。この体重動摇 は尿量の增減と関係深く尿量が激減するとその 後に必ず体重が増加して抢り時として浮腫が認 められた。

その他尿所見として重要なることは Ehlrich のUrobilinogen 反応が現れることである。こ れは低蛋白食の比較的初期より現われ，恢復食 期に入って蛋白が豊富になると急激に消失す
る。元来尿の Urobilinogen 反応は稂知の如く肝臟機能 障害に際し强く現われるからこれも恐らく低登白食によ る肝茷機能障害であろう。

その他糖蛋白アセトン等は常に陰性であった。咒蛾に はアセトンが陽性になるといわれるがこの場台には多最 の含水炭素が与えら机ているから陰性となるのが蜜ろ当 然である。

第 1 四被検者 $\mathrm{Ha} 51.7 \mathrm{Kg}$. $\hat{0}$

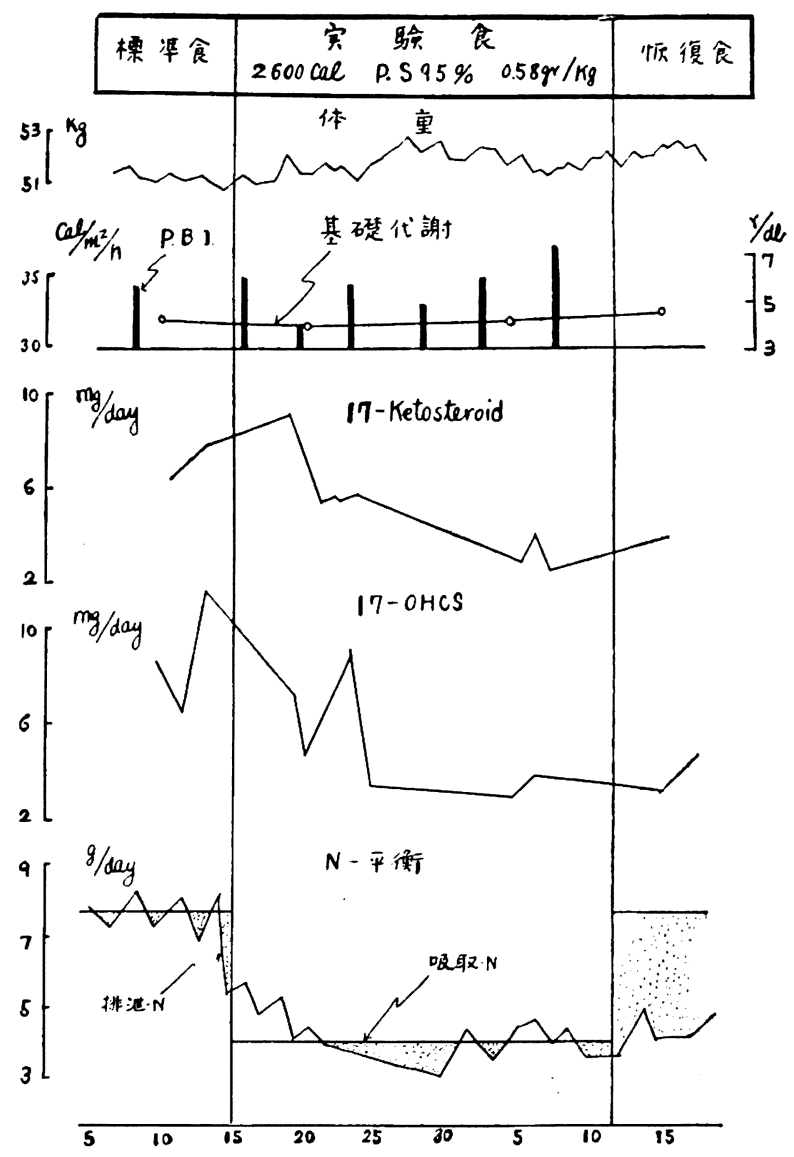


2）窒素出納実験と基硞代即ならびに血清 P. B. I.に ついて：第 1 図は高蛋白価低蛋白食の代表的な一例 $\mathrm{Ha}$ についての成績を図示したものである。まず蛋白代謝の 変化について述へると食蛋白量を標準食から低蛋白食に 変えた場合，尿排泄 $\mathrm{N}$ 量は直ちに一定のレベルに低下 するものではなく食蛋白量を切換えると共に尿排泄N昆 は漸次減少してこれに適応寸るようになる。

この図で見ると約 7 日問を経てその低下は新しいレ心゙ ルに落付きその状娊を保持しつつ安定した平衡を保って 経過して行く。その排泄 $\mathrm{N}$ 盟は 3-4 gr/day であり吸 収 $\mathrm{N}$ 量は $3.6 \mathrm{gr} / \mathrm{day}$ であるからほぼ製平衡を保ってい ることが判る。

次に第 2 図はこれと同じ関倸を低蛋白価低蛋白食の一 例について図示したもので吸収 $\mathrm{N}$ 量と排泄 $\mathrm{N}$ 量が平衡を うるには約 2 週問を経過して始めて零平衡に達する。即 ち両者の間には1週間の平衡時間のうれれがあり,その間低 蛋白価低蛋白食例ではかなり著明な負出納が長くつづい て経過することが判る。空素出納が負であることは体蛋
白の崩壊量の方が合成量よりも大きく，組織蛋白の消耗 を招来することを意味している。そして図示のよ5に激 しい負出納の最後に到達して尿空素のレベルは Folin9) 所謂「内因性窒素量」か，あるいはそれに近いものと考 えてよいであろら。これと同じ関倸は B 群の実験におい ても証明され，非必須アミノ酸を添加した方が速かに零 平衡に到達している。一方第 1 図高蛋白価低蛋白食実験

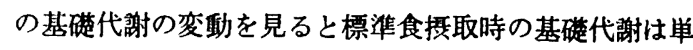
位面稍当り 1 時間平均 $33.88 \mathrm{~K} \mathrm{CaI}$. であり低蛋白食に移 行して後もほとんど変化を示さず䇪素出納が零平衡に達

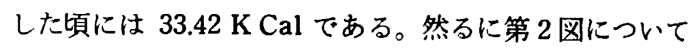
推察すると標燞食期平均 $34.83 \mathrm{~K} \mathrm{Cal}$ の值を示寸基碮代 部は低蛋白に移ると食荃価は充分なるにかかわらず僅か に減少の傾向を示し，その後顕著に減少して著明なる低

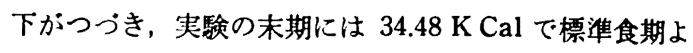
り10\%の低下を示すに到るのである。この関係は高蛋白 価低蛋白食の場合と著しくおもむきを異にしており， 低蛋白食 3 週間の平均值と標準食期平均値との差は高蛋

第 2 図 被検者 Ue $57.5 \mathrm{Kg}$ 。 $。$

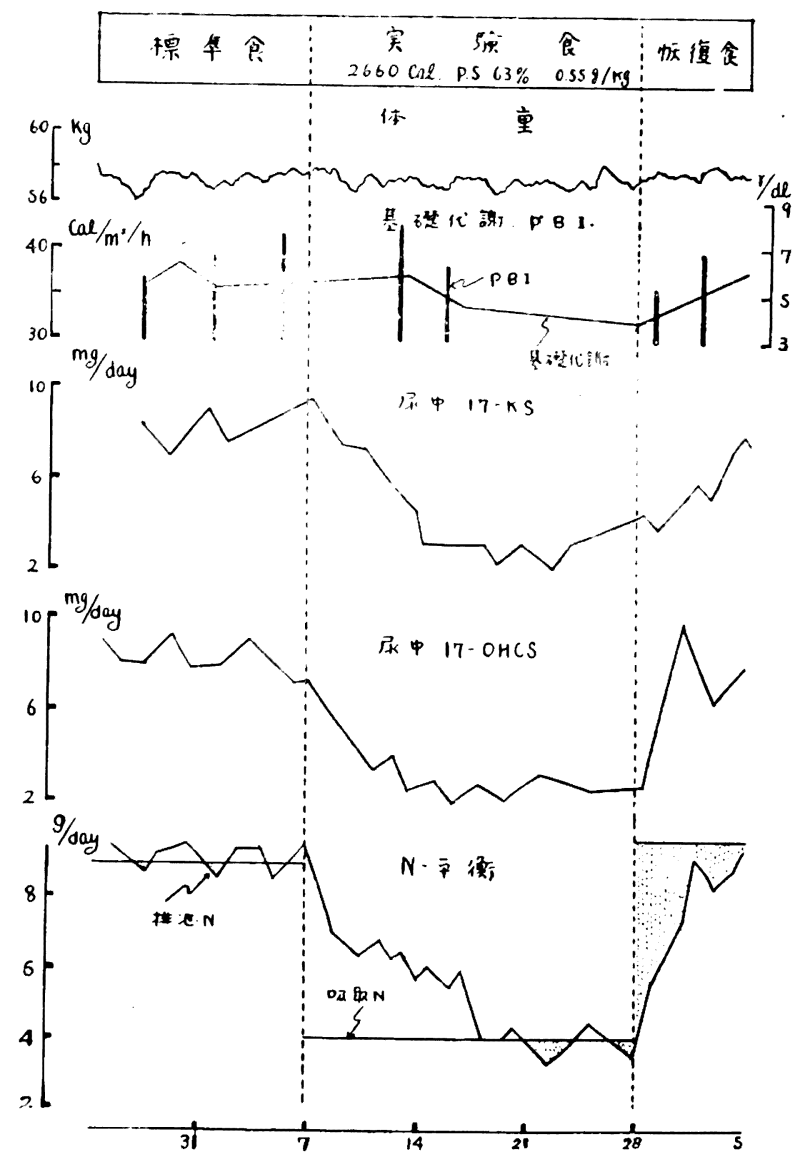


第 3 因被検者 $\mathrm{Ka} 22$ 才 $\delta$

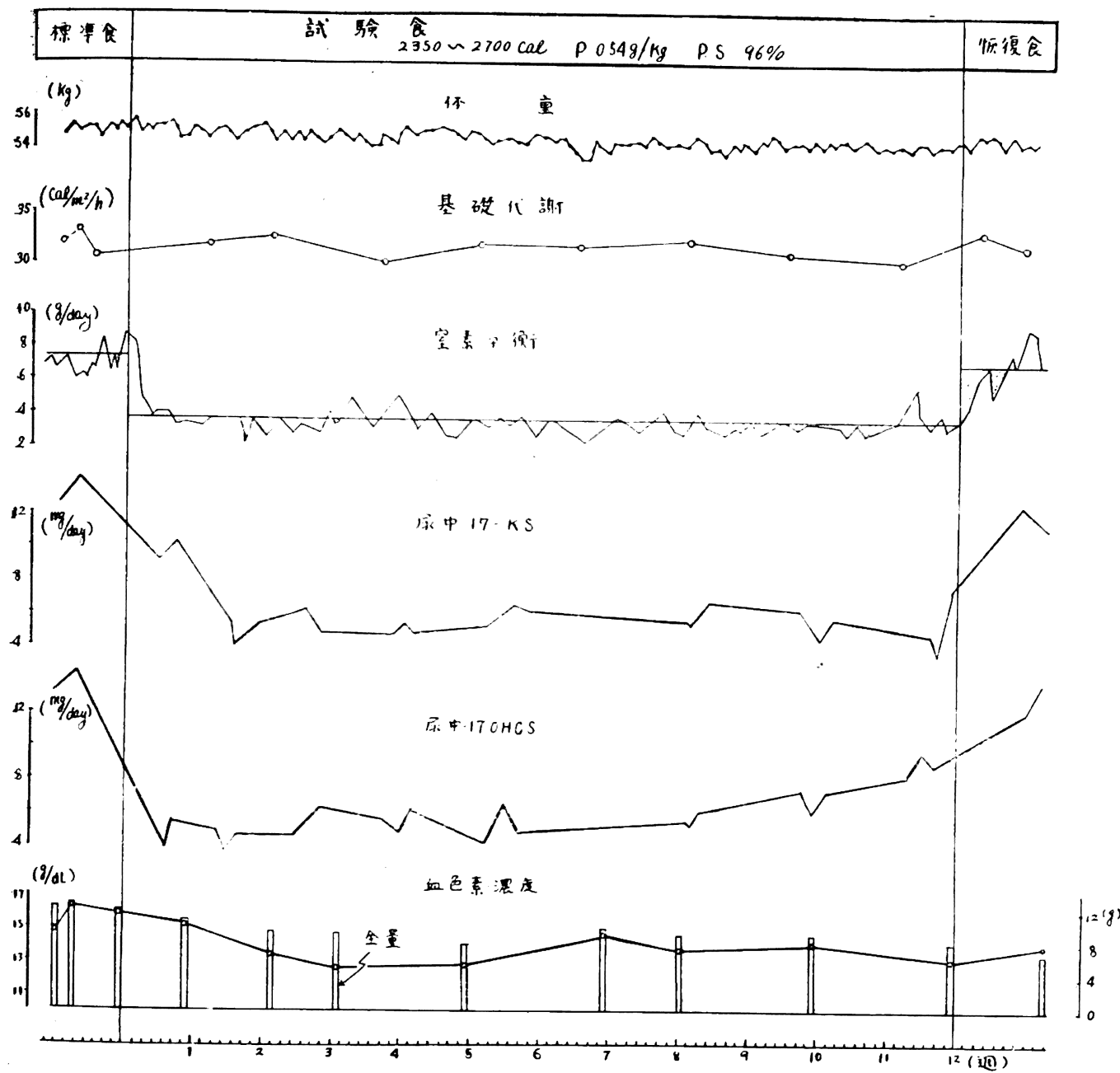

白価低蛋白食例ではほとんど認めがたいが低蛋白価低蛋 白食例では著明な差を認め，激しい場台には標準食期に 比し10\%の減少を示す例もある。

また長期低蛋白食実験においてもこの食聑内容は第 1 図の例と同じく高蛋白価低蛋白食に一致しており100日 の後においても基礎代謝には変動を認めがたいのであ る。これは第 3 図に示したここのように高蛋白価低蛋白 食と低蛋白価低蛋白食では一方では100日省経過しても 基硔代锹は低下しないにもかかわらす，低蛋白価低蛋白 食では10日前後において上記の如き影著な低下を示す事 実ははなはた興味哚いことである。この差の原因として はさきに指摘した場合の体内窒素脱出量即ち体蛋白消耗 の大きい事実を考え合わさねばならない。食触性蛋白の 倛給が減少した場合にはその久その度に応じて体蛋白の 消耗が起るがこの場合消耗が軽度ならば基礎代謝に変化
が現われないが，体䖵白の消耗が著しくなって体内固定 蛋白にまでひびくようになる上基礎代謝组の変化も頙著 になることは寸でに吉村教授10)の指摘した上ころであ る。この場合吉村教授は蛋白消耗が強くなって原形睬の 酸化現象を営む蛋白の消耗にまでおよぶから基礎代愔を 娍す゚ると説明されているがこの場合の血韲 P. B.I を測 定して見ると基礎代謝の減少した時には必ずといってよ い位に P.B.I の減少庄来している。従って低蛋白食に よる基礎代謝量の変化は固定䖝白の消耗によるというよ りも寍万甲状腺が低蛋白食によって体蛋白消耗の影響を 受けてその生理的適応現象として機能を低下寸る結果に よるものでああろう。

3）尿中排泄副腎皮質ホルモン：第 4 図は短期低蛋白 食実験の被検者 6 名について，また第 5 図は長期低蛋白 食実験の被検者 4 名について尿排泄副筲皮質ホルモン 

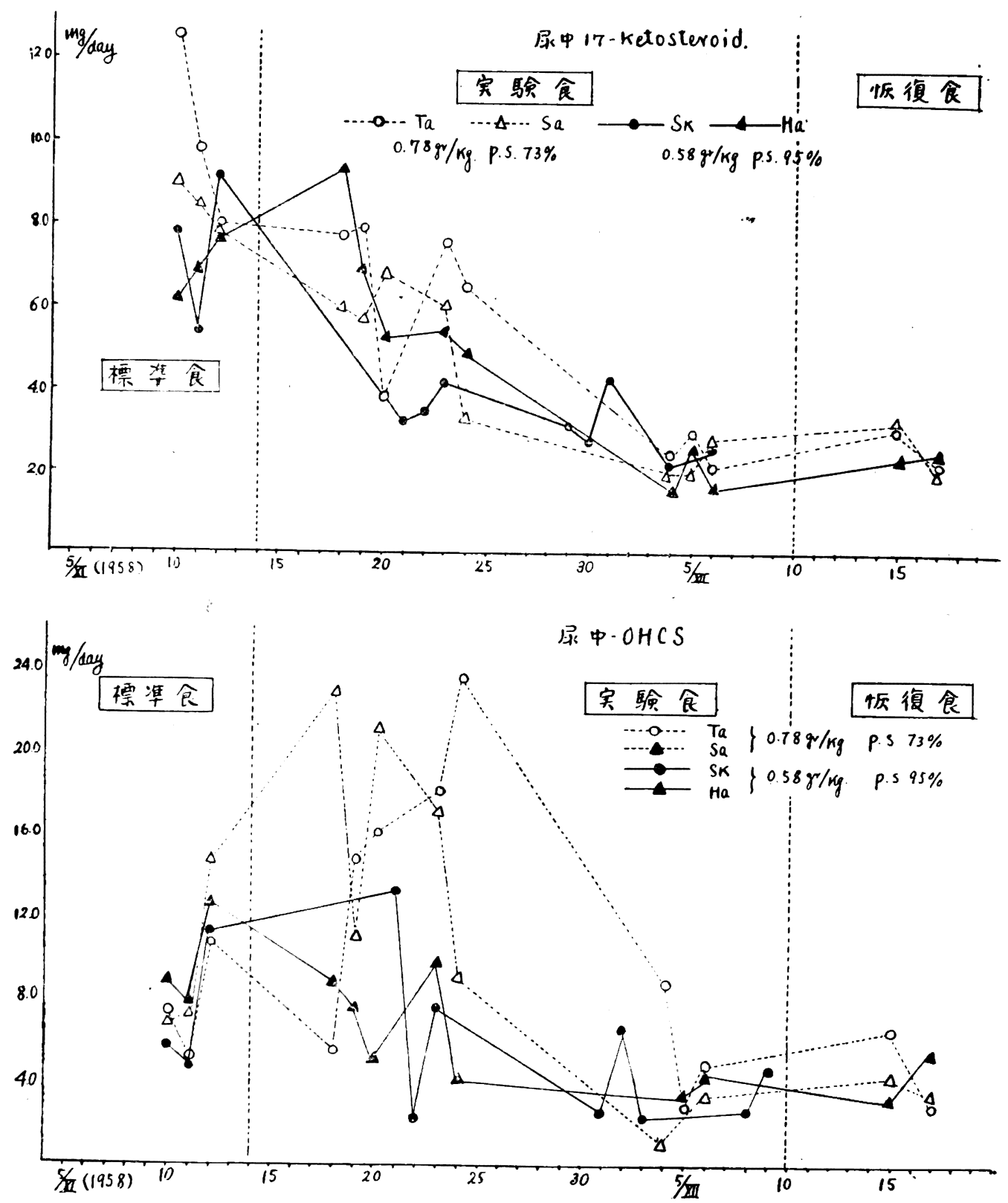
17-KS 及び 17-OHCSの分必量の状況を曲線で示した しのである。各被検者の曲線はその拯取せる低蛋白食の 理類によって3種類に分けた。まず第 4 図を見るに低蛋 白食期に入ると 17-KS と 17-OHCS は共に漸次減少 を示し20日前後において最低価に達する。この点いずれ の被検者の場合も皆同样の傾向を示しており，蛋白食の 负的差異の影锌についてはあまり著明でない。第 5 図は この種蛋白食を更に長期にとらせた例であるが図示の如 く3㥜間頃より以後やや增加し元値に恢復せんとする様 子が見えるが完全に標準食期の状態に恢復するものでは なく，ある程度低いレベルで低蛋白食期終了まで持続し ている。そして恢復食期に入ると共に顕著に增加し，標 準食期を上回る上界を示している。これらホルモンの個 タの测定值はかなり動摇が激しく且個人差も著しいので 各蛋白食種別の比較をなすにはこの図では不明である。 そこで標準食期におけるそれそれ被検者の平均值を 100 とし低蛋白食の経過と共汇副腎皮質ホルモンの減少
する状況を\%を以て示したのが第6図である。この聥減 の状況は一般状热のところで述心゙た如く被検者の自觉症 状とよく一致与るところであ门，低登白食期に入って20 日前後の 17-KS 及び 17-OHCS 上びの雨到篎皮質木 ルモン分必易が最低倠走示寸頃になる上被娭者は著しい

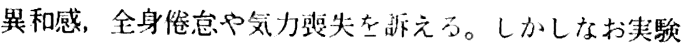
在継統して行くと自觉症状は自然:消退して何の苦痛も 感ぜず実駼終了に扩上んでいる。

そして長期低监白食実験の成緹に扮: 一その影響を蛋

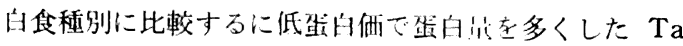

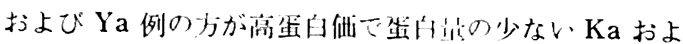

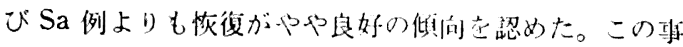
は低蛋白食事の血色素量の減少につ!、吉阔が行なった 比較についても同様の事がいえるのであって，蛋白の筫

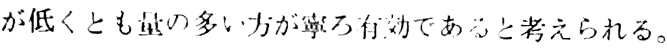

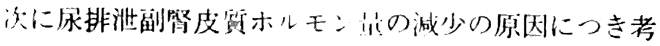

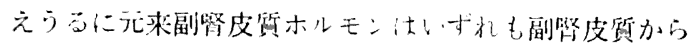

第5因長期低䍃白食夷跧

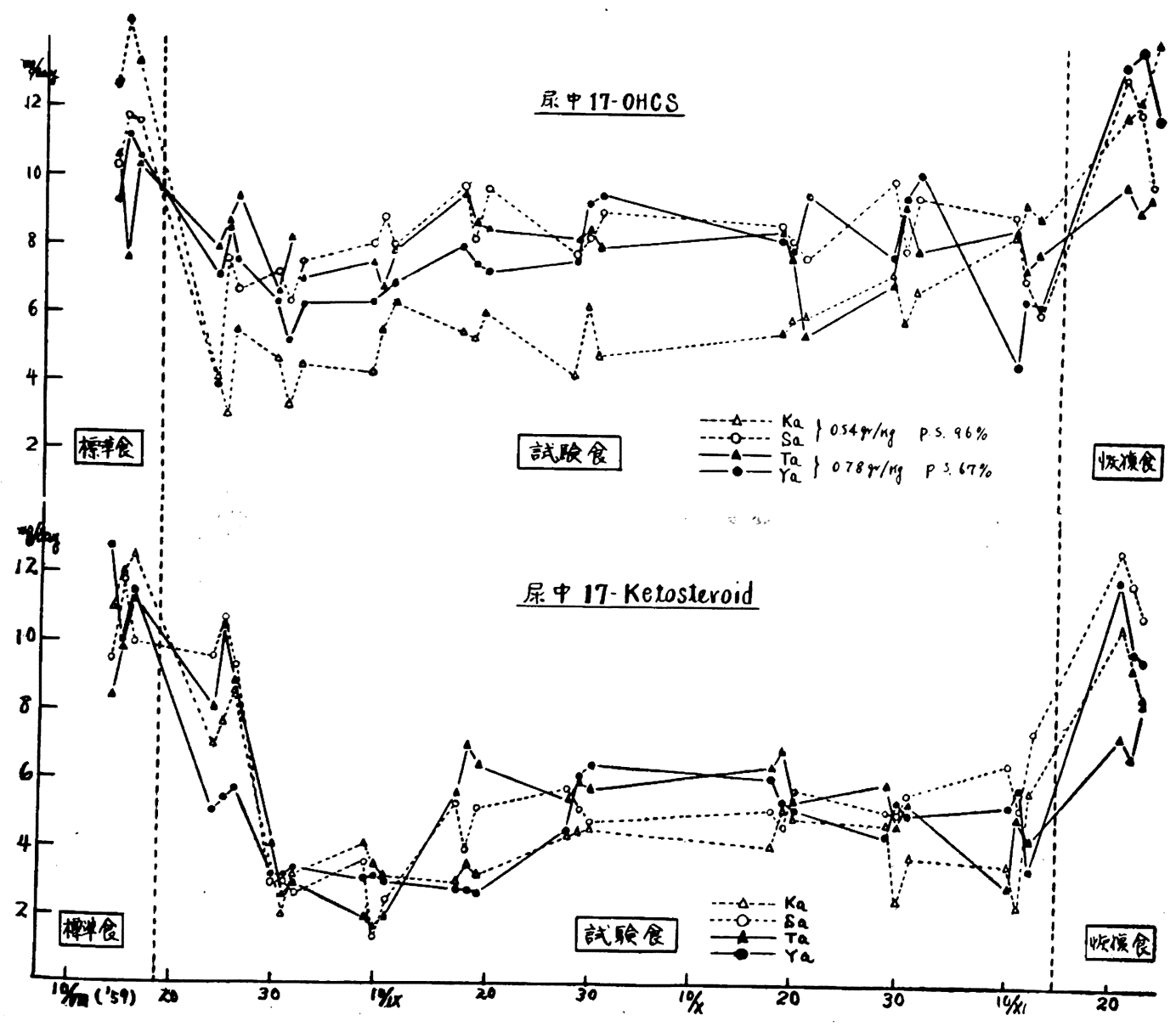


血中に分泌され，血清グロブリンに㹩く吸着した形とな って徝環し肝臟に到って変形あるいは非動化されて後尿 中に出て来る。従って肝臟によって処理せられる程度が 強いと尿中への排泄量が減ずるものである。

低蛋白食期には終始 Ehrlich 氏 Urobilinogen 反応 が陽性である事などからも推察せらるるように食蛋白の 久乏に際しては肝機能障害のあることは明らかであ。 下、副督皮質木ルモン減少の原因在肝機能に求的ること は困難であり，この尿中副督皮澌ホルモンの減少は明ら かに食全白欠乏に上る副腎皮質機能低下に原因寸るもの と判定せられる。

次に符 1 図および第 2 図においてはそれでれ代表的な 2 例について蛋白代謝㧍よび基喏代射，血清 P. B.I と 尿排泄副腎皮質ホルモ之分泌昆の相関性を示しているが

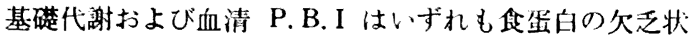

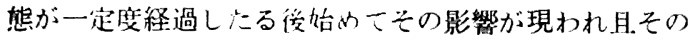
成績には一定度の食督白欠乏の状況が/映せられている が副腎皮翼ホ儿モンの減少仗低蛋白食期に人る上直ちに
鋭敏に減少が始まる。そして食蛋白欠乏の程度と副督皮 質ホルモン分泌量との間には明らかにいいらる因果関保 を見出し難いのである。併し強いていえば短期実倹に和 ける Ta 例㧍よび Sa 例の如く例え蛋白の倎は悪くとも 最の多い方が副腎皮質ホルモン分泌量減少に対する影鹤 は少ないようでありこれは長期低蛋白食実験について 述べたと同しである。またこれと同しこことが B 解の実 呀でも更に比較的明膫に現われている。

即ち第 7 図に示した如く副腎皮質ホルモン分泌減少に 対する影響は必須アミノ酸のみを添加した Ka 例および KOt 例の場台よりも，必須アミノ酸に加うるに非必須了 ミノ酸たるグリシンとグルタミン酸を併せ添加した Ku 例およびUe 例の場合の方が影響は少ないのである。ま た $\mathrm{N}$ 出納の零平衡に到達する時間的関倸にも両者の間に 明眿な差が認められており, 非必須アミノ酸添加グルー プにおいて非常に早く零平衡に達するのである。この点 から考えても必須アミノ酸のみの添加の場合とそれに更 に非必須アミノ酸たるグリシンとグルタミン酸を添加し

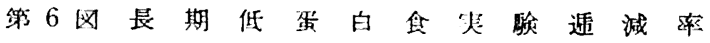

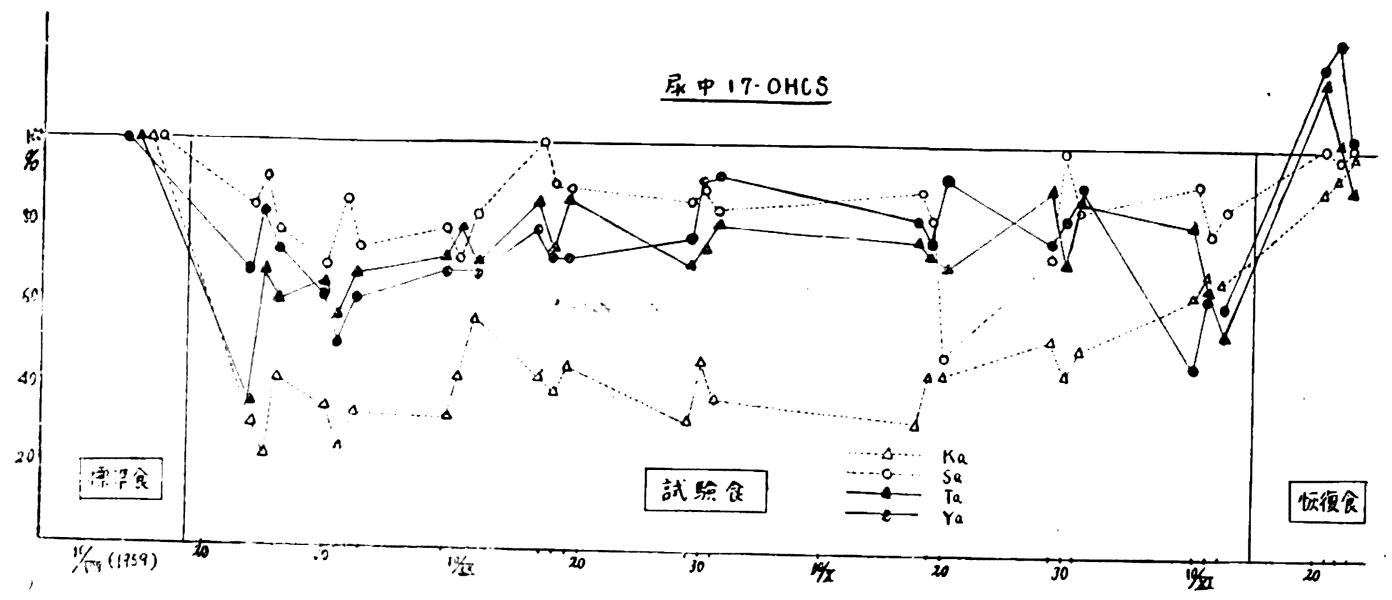

康中17-Ketosteroid

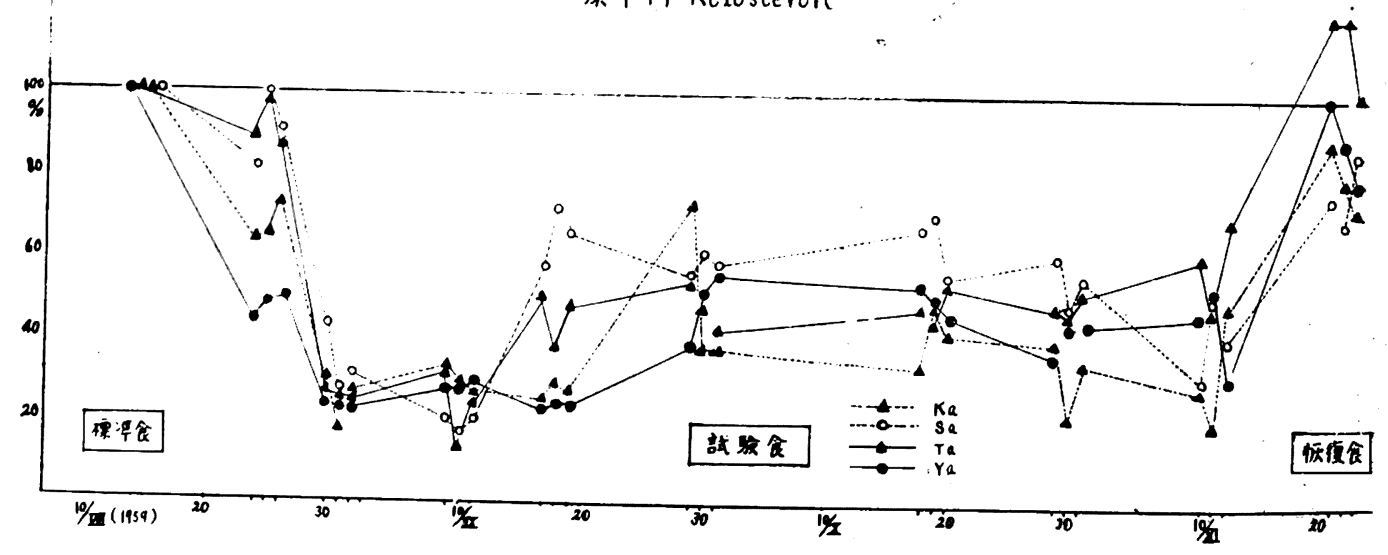



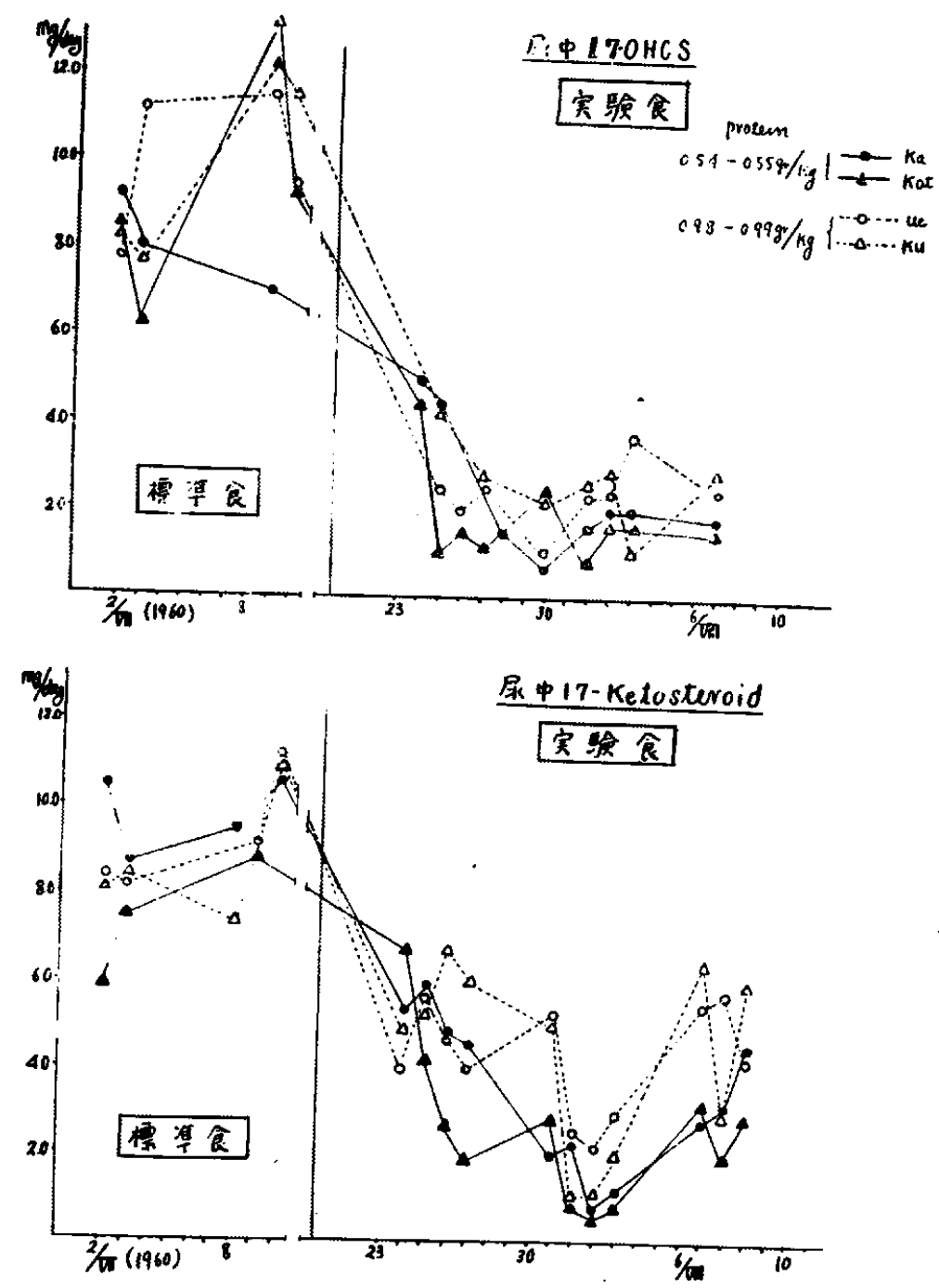

た場合とでは生理機能におよぼす影管が異ること注明睹 で、副等皮質ホルモン分泌量との間には相関性が譙明出 来る。

\section{II 僧堂生活者における調査}

僧堂の食生活の大要は第 4 表の食领拥䍒表に示されて いる。この表に見る如く，食養価，蛋白量の平均値はそ れぞれ 2423 Cal および $61.7 \mathrm{gr}(1.14 \mathrm{gr} / \mathrm{kg})$ であって この再者加見ると日本人の健康成年男子の標準食に近 い值である。しかし蛋白洒化ついては全く動物性蛋白を 含まず，雄類豆類野菜等を主とする植物蛋白のみである から平均 63\% に過ぎない。こは著者の行なった長期 低蛋白食人体実䟻の (2)の場合と殆んど同条件の食䁒と
いうことが出来，ただ人体実呀の場合に比し，婹取蛋白 量をより多くとっている。要約すれば肵の悪い蛋白犋を 充分に与えた食触である。

第 8 図はかかる食生活を 2 力以上（長いしのは 7 年 間）続けた僧侣について尿排泟 17-KS および17一 OHCS を測定し，これをヒストグラムにて示したもの である。国には同時にほぼ同年令の健康成年男子を対照 に選び，その1 日 Steroid 排浛量を測定して同图右端に ヒストグラムで表示した。一見明膫なる如く僧堂生活者 は普通食慨の成年男子に比して尿 Steroid 排澌量は影著 に低くその平均についていえば 17-KS の場合は対照の 平均 $9.7 \mathrm{mg} / \mathrm{day}$ に対して僧侣の平均値は $6.0 \mathrm{mg} / \mathrm{day}$ であり，17-OHCSの場合は対照值 $9.6 \mathrm{mg} / \mathrm{day}$ に対し 

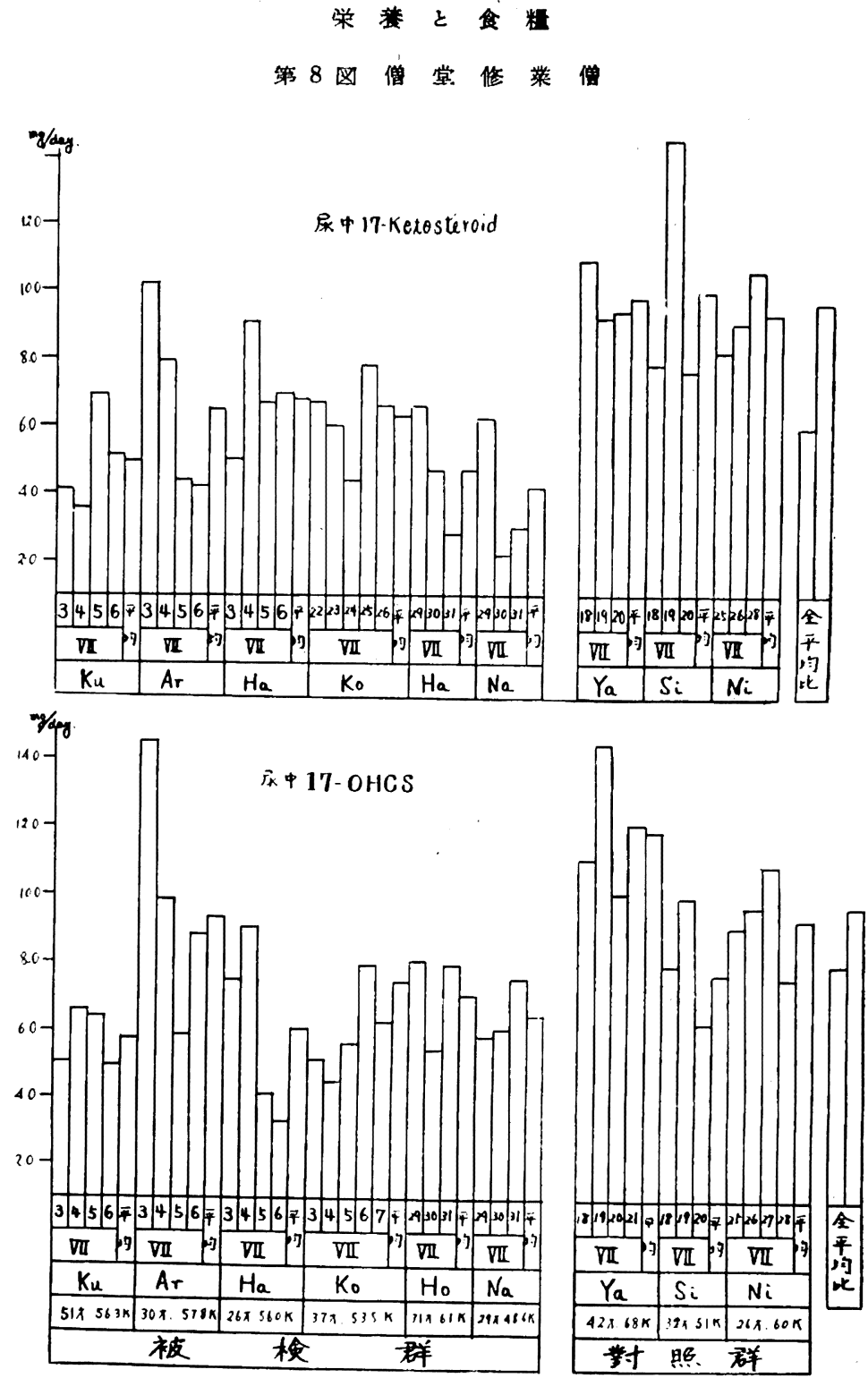

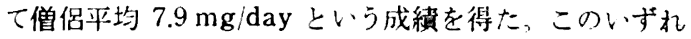
の Steroid 排泄量においても僧侶の方が推計学的に有 意に低いこ上が示されている。今著者が測定した健康成 年男子 17 名について僧侣調查を行なったと同じ夏の季 節における1 日尿中の $17-\mathrm{KS}$ および 17-OHCS につ いて頻度分布図を描くに第 9 図の成績が得られる。この 図の中に僧侶について調查した成績を黒く塗りつぶして 示してみた。

図示の如く両副腎皮倎ホルモンの僧堂生活者について の測定值と健康成年男子についての測定值の分布状況を 比較する上前者は後者の中半以下に低く分布しているこ とが判明した。
なおこれら僧堂生活者の一般状態についても被検者は 自覚的にもまた他覚的にも全く異常所見を認めず，尿検 查, 血圧測定值，心電図所見等にも異常がなく，一般の 食事をとる場合と変りなく僧堂の生活を送っているので ある。また同時に測定した基嗼代謝は最高 $38.44 \mathrm{Cal} / \mathrm{m}^{2} /$ $\mathrm{hr}$ 最低 $35.49 \mathrm{Cal} / \mathrm{m}^{2} / \mathrm{hr}$ であって正常値を示しており， 体格や栄養状態についても特に記載を要する如き所見は 認められなかった。

考按

以上著者の実験においては低蛋白食の条件を各種に変 更することにより，生理機能就中内分泌腺機能に対する 
第 9 因僧侣及び传康成人男子の比较分布

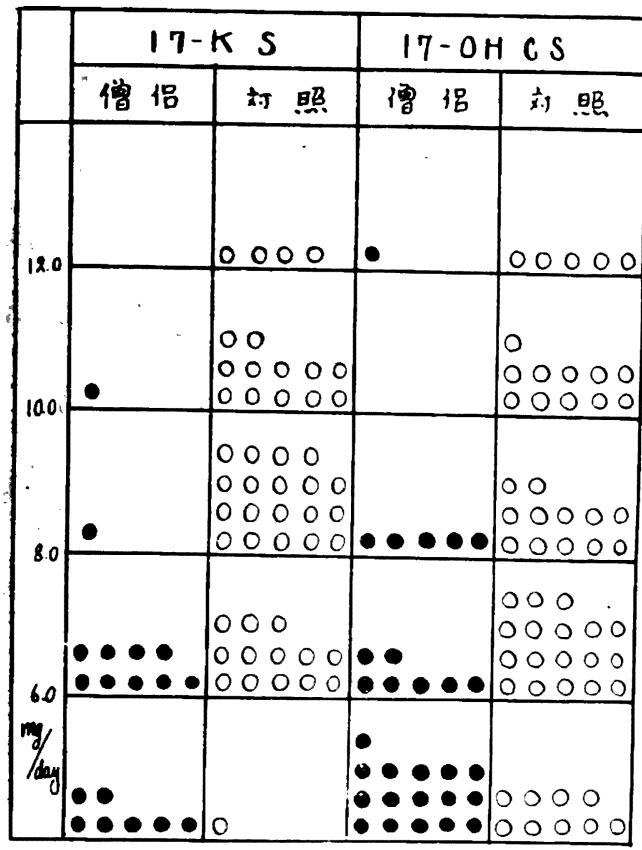

影䇺を锶察したものであるが蛋白久乏が空素出納、基喏 代新, 血液性状等の生理機能:こ対する影響については既 に今日までに当教室で実施されて来た多くの業績11)12113) に詳細に亘り報告されているのでここでは尿排泄副腎皮 啠ホルモンの測定值から考えうる蛋白久治の生理的影響 について論ずる。

既に述べた如く各種の低蛋白食を以てした人体実験に 於て第一にその窒素平衡の問題を検討したが何れの場合 にも必ずよく空素平衡の保持せられている点を強調して おいた。しかし同時に測定した尿排泄副腎皮質ホルモン は低蛋白食期に入ると漸次堿少し二来るのであって2 3 週後には最低值を示すこ上が明らかにされた。一体尿 中の副腎皮澌ホルモンは副腎から血中に出て肝满に到っ て非動化されて尿中に出るのであるが蛋白欠乏食では肝 機能は弱められ，茅ろ機能障碍が起っているのであるか らこの低下は当然副腎皮質の分泌機能そのものの低下を 考えなければならない。

この点から考えると例え蛋白量か空素平衡を保つには 充分であっても必ずしも生理機能が完全に满されている とはいえない。

従って蛋白必要量を決定するには窒素平衡が保持され ているか否かの問題のみでなく，血液性状やホルモン分 泌量等を参考にして，正常なる生理機能が完全に保持出 来る蛋白必要量を決定することが肝要である。

次に著者の行なった長期低蛋白食実倹に明らかにせら
れた如く低蛋白食 $2-3$ 週の頃に银低となった尿排泄副 肾皮質ホルモン量はその後漸次增加の傾向を示しつつ, 完全には標準食期の状態に復帰しないままに契験終了に およんだ。これは明らかに蛋白欠そ状態に対する生体の 制化を示すものである。かかる状況はまた低蛋白食の人 体実験に掞いて被検者が訴える自觉症状ともよく一致寸 る処である。しかして注目すべきことは低登白食であっ ても高蛋白価で量の少ない場合と低蛋白佃で聂の多、場 合とを比校して見ると各種の生理機能に対しては後者の 方がより影響が少ないことが著者の行なった二つの実験 から証明された。この問題が日常生活に実行せられてい るのが単宗僧堂における食生活である。即ち落者の行な った食解調查と僧侣の尿中副㹂皮質ホルモン分必星の測 定做からすると僧堂における食生活はこのような路が多 くして且質の悪い食怔をとっている訳であってこれによ って副腎皮啠ホルモンの分泌鼠各低下せしめる一方他の 生理機能には極力影整を少なくせんとしているので亦 3。

しかしてここに測定した 17ーーKS 跸腎より分必せら れる男性ホルモンを代表するものであるが元来僧侶に男 性ホルモン分泌が旺盛であることは好ましい事ではない からこのような食生活は僧堂におけっ修業生活に対し て極めて意義が哚いといわ极ばならな!，即ちここに比 寉山の遠く人里を離れた山深い環境において長年つうけ られた僧堂の食生活も近代医学より考えて極めて合理的 な戒律が行われていることが明らかにせられた訳でる あ。

\section{総括}

健康成人男子を被検者として低蛋白食人体実駼实实施 し蛋白欠乏食が尿排泄副肾皮質ホルモン分泌星におよぼ す影響を検討し，同時に習慣的に低蛋白食をつうけてい る禅宗僧堂における修業僧についてその食佃調查を行な う上共に尿中排泄副腎皮質ホルモンを测定して次の結果 を得た。

1）標準食から低蛋白食に人ると副繁皮質ホルモンた る 17-KS, 17-OHCS 仗共に漸次減少し第 2-3 週に おいて最低值に達しその後やや增加の倾向を示すが標淮 食時の做にまでは恢復することなく低位を保ちつつ奜験 終了におよんだ。この関係は低蛋白食による被検者の自 覚症状上もよく一致し，最低值を示す 2-3 週の頃に自 覚症状が最も強くその後は漸次自然に消退するものであ る。これは副腎皮質機能に一元の制化現象が現われる為 であろう。

2）低蛋白食期に人る上尿中排泄の空素暴は渐次減少 して吸収 $\mathrm{N}$ と排泄 $\mathrm{N} か ゙$ 出納平衡を保持するよらになる。 
かかる等素の零平衡に到達する時は従来の考え方よりす

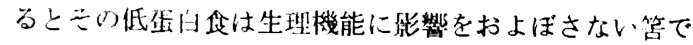

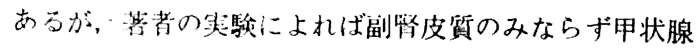
の内分战機能が低下して本る。従って生理機能を維持す るための蛋白必要点汁江等素出納平衡のみに依存して 決定するここなと，他の低蛋白食の生理的影智に注意す べきである。

3）全く動物䄈白在掑取していない禅宗僧堂において

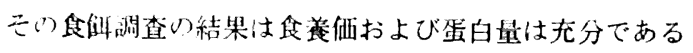

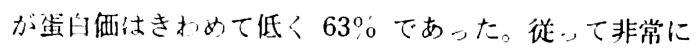

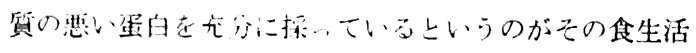
の特微である。

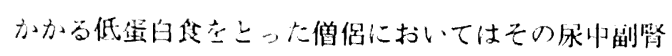

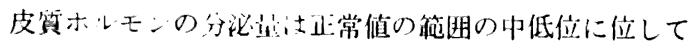
いる: いくの姐き副婜皮質ホルモンことに17一KS 系の ホルモン分泌が少ない壮は僧侣の修業生活を続ける際, 非常に有觉花てある上判断せられる。

稿省終すに志にり御愁篤なる御指導上御校閲を睗った 吉村教授に谐く感时の意在表します。

\section{文献}

(1) Roch, M: Ann. Nutr. At Alim. 11 (No. 3-4)

(2) 正木: 臨床とホルモン (1959)

(3) 吉村: 本龍, 9, 1 (1956)

(4) 增田: 日新医学 $38(546-549)$

(5) 鳥居: 臨床とホルモン (1959)

(6) 藤井：生化学実臨法 (定量第)

(7) Baker S. B et al: J. Clin. Iuvest. (1951) 30. 55.

(8) 森田：日新医学 45 (10号・11 号)

(9) Folin. O; Am. J. Physiol. 13. 117 (1905)

(10) 吉村: 日新医学 4 (1 号)

(11) 吉村外：日新医学 39, 641 (1952) 㧍よび 41, 188 , (1954)

(12) 山本：本誌，5，210 (1953) 㧍よび 6, 163 (1954)

(13) 井上: 日本生理誌 16, 216 (1954) 扩よび 16, 326 (1954)

（京都府立医科大学）

（経損著者負担）

\section{ワラビのー種から得た耐熱性抗アノイリン因子の作用機作と，その精蟞}

水抽比液をイオ:交換樹脂法で一応精製したものをサ イアミンに添加する上その活性の $80 \%$ を失なうが，ピク リン酸壏としての桧討によればサイアミン分子自体は破 壊されていないこ上がわかり，阻害混合物から陽イオン 交換㴻脂を用いて原量のサイアミンが回収できることか ら，阻嗐はサイアミンとこの因子のコンプレックス生成 によるものとした:この因子を,ブルミン塩形成, イオ 二交换樹脂吸着，向流分配などで，さらに分別した各画 分の抗アノイリン活性を「50阻害一テスト」で検尉し， 同時にその性状を述べている。活性の高い画分は $285 \mathrm{~m} \mu$
の吸収が著しい。

Der Wirkungmechanismus eines gereinigten Antianeurin faktors aus Adlerfarnkraut.

J.C Somogyi, A. Koller: International $Z$. für Vitamin forschung 31 (2) 227 229 (1961) Weitere Versuche zur Isolierung eines thermostabilien Antianeurin wirkstoffes aus Adler farn kraut

A. Koller, J.C. Somogyi: Ibid, 31, (2) 230 233 (1961)

(安 沓) 